\title{
A Case Report of Ultrasound Guided Stellate Ganglion Block for Peripheral Vascular Disease in Critical Care
}

\section{Yoğun Bakımda Periferik Vasküler Hastalık için Ultrason Eșliğinde Uygulanan Stellat Ganglion Bloğu Olgu Sunumu}

\author{
Illksen Dönmez', Aysu Hayriye Tezcan', Mesut Öterkuș', Ömür Öztürk², Eșref Erdem' \\ ${ }^{1}$ Kafkas Üniversitesi Tip Fakültesi, Anesteziyoloji ve Reanimasyon Anabilim Dal,, Kars; ${ }^{2}$ Çanakkale 18 Mart Üniversitesi Tip Fakültesi, \\ Anesteziyoloji ve Reanimasyon Anabilim Dal, Çanakkale, Türkiye
}

\begin{abstract}
A 72 year old female patient was in critical care secondary to acute coronary syndrome and acute cerebrovascular event. Secondary to patient's significant blood pressure alterations, she was monitorized with radial artery cannulation for invasive blood pressure follow up. During the follow up patient's right hand circulation deteriorated. In terms of this kind of acute ischemia; anticoagulants, vasodilators and sympathetic blockage are alternative treatment methods. As an example of upper extremity main sympathetic blockage; stellate ganglion block was performed with ultrasound guidance. In this case report we defined the beneficial effects of stellate ganglion block and complication protected effects of ultrasound in critical care.
\end{abstract}

Key words: stellate ganglion block; ultrasound; upper extremity ischemia; radial artery cannulation

\section{ÖZET}

Yetmiș iki yașındaki bayan hasta akut koroner sendrom ve akut serebrovasküler olay nedeniyle yoğun bakımda yatmaktaydı. Ciddi kan basıncı oynamaları olan hasta invaziv kan basıncı takibi için radyal arter kanülasyonu ile monitorize edilmiști. Takipleri sırasında sağ el dolașımında bozulma tespit edildi. Antikoagülanlar, vasodilatör ilaçlar ya da sempatik bloklar bu tarzda olușan akut iskemilerde kullanılan tedavi metotlarıdır. Üst ekstremitede kullanılan sempatik bloklara örnek olarak bu hastada ultrason eșliğinde stellat ganglion bloğu uygulanmıștır. Bu olgu sunumunda stellat ganglion bloğunun yoğun bakımdaki faydalarından ve ultrasonun ișlem komplikasyonlarını azaltıcı etkilerinden bahsetmek istedik.

Anahtar kelimeler: stellat ganglion bloğu; ultrason; iskemi; radyal arter kanülasyonu

Aysu Hayriye Tezcan, Kafkas Üniversitesi T⿰力丶 Fakültesi, Sağlık Uygulama Arasttrma Hastanesi Kars - Türkiye, Tel. 05326735711

Email.aysndr@gmail.com

Geliş Taribi: 09.01.2017 • Kabul Taribi: 03.03.2017

\section{Introduction}

Ischemic changes may be seen in the extremities due to various factors during the hospitalization period in ICU patients. These factors include radial artery cannulation, accidental intra-arterial interventions, embolies, vasoactive drugs and pre-existing diseases of patients. For significant ischemic events, different methods of treatment are used alone or in combination. Sympathetic system dysfunction with brachial plexus block or stellate ganglion block are the interventional methods used for treatment. However, the application of this block with a wide spectrum of cases may cause serious complications due to anatomic placement ${ }^{1}$. So ultrasound guided stellate ganglion block becomes more important than usual.

In this case report, it is aimed to present the beneficial results of ultrasound guided stellate ganglion block in addition to medical treatment in a patient with ischemia in the right hand.

\section{Case}

A 72-year-old female presented critical care with acute coronary syndrome. Coronary angiography was performed and clogged arteries opened with stent application. Her pre-existing disease history includes atrial fibrillation, diabetes mellitus, hypertension, coronary artery bypass grafting, left leg amputation secondary to previous car accident. In the second day of the revascularization patient's cardiac performance impaired, respiratory failure occurred and she was intubated and mechanically ventilated. During the following days renal impairment emerged secondary to contrast 
induced nephropathy. In addition to routine noninvasive vital sign monitorization (electrocardiogram, peripheral oxygen saturation, temperature), radial artery cannulation and central venous catheterization applied for closed blood pressure and central venous pressure monitorization. Patient needed noradrenaline infusion for deep hypotension for two days. Renal impairment declined with medical supportive therapy without hemodialysis. In the two following days heamodynamic variables become more stable and invasive radial artery monitorization was terminated. Two days after displacement of radial artery cannula circulatory disturbances were observed like poikilothermia and pallor in right hand fingers. For medical therapy arm elevation performed, low dose nitroglycerin infusion was started. Patient had received enoxaparin sodium and clopidogrel already because of coronary perfusion. In the following day circulatory impairment progressed besides medical therapies. It was decided to perform stellate ganglion block. Ultrasound guided stellate ganglion block was performed with C7 anterior paratracheal approach and $10 \mathrm{~mL}$ bupivacaine $0.25 \%$ was used. Temperature monitorization was applied in the palm of the hand. Stellate ganglion block was repeatedly performed every other day. Right hand temperature increment occurred at the first day of the block and perfusion amelioration was observed at the second day of the block. The level of ischemia gradually decreased. However, the patient died due to multiple organ failure on the 10th day of the intensive care unit as a result of the myocardial insufficiency.

\section{Discussion}

Radial artery cannulation is commonly used in intensive care units, operating rooms for blood pressure measurement and frequent arterial blood gas analysis. The most common side effects of this procedure are transient radial artery occlusion and hematoma. Infection, bleeding, progressive ischemic injury, and pseudo aneurysm may also occur in the artery. After a short period of catheterization, there was only regional damages around the cannulation site. Long-term and permanent radial artery occlusion development was also described. In some cases, occlusion of the radial artery occurred after a few days of cannulation or removal of the catheter ${ }^{2}$. In our case, ischemia began to appear two days after the removal of the radial artery cannula. It was thought that there was occlusion at finger arteries due to cannulation and partial perfusion of the radial artery was observed.
Anticoagulant therapy is an important step in the prevention and treatment of thrombosis in arterial interventions, accidental intra-arterial injections, and other embolisms ${ }^{4}$. From the first day of our patient's intensive care, LMWH treatment was applied prophylactically. Under this treatment right-hand circulatory disturbance developed.

Ghori et al. reported that extremity elevation prevented the development of edema and compartment syndrome ${ }^{4}$. We got our patient's right arm elevated to prevent edema development.

Tutuncu and colleagues successfully stopped the development of ischemia with a continuous brachial plexus block, which they applied in addition to medical treatment in a case of accidental ischaemia resulting from intra-arterial injection, and successfully treated circulatory disorder ${ }^{3}$.

Stellate ganglion consists of inferior cervical and first thoracic sympathetic ganglion. Ganglion block is used for diagnosis and treatment of hyperhidrosis and vascular diseases due to sympathetic system dysfunction as well as chronic pain treatment ${ }^{1}$. Major indications related to vascular diseases are Raynaud's disease, freezing, vasospasm, Buerger's disease, arterial injuries, embolic vessel diseases, radical breast surgery and lymphedema following freezing ${ }^{1}$.

Sympatholysis secondary to peripheral nerve block results in arterial and venous vasodilatation and weakens reflex vasospasm. This effect increases tissue perfusion and reduces ischemic pain. Many practitioners used peripheral blocks for sympatholysis. Kessel applied caudal block for this purpose and achieved a successful result ${ }^{5,6}$. Ozdinc and colleagues performed brachial plexus block in addition to medical treatment in a case and achieved successful results with uneventful recovery of extremity ischemia ${ }^{7}$.

The local anesthetic volume varied between $5-20 \mathrm{~mL}$ but ultrasound guidance ensures lower doses of the drug. The drug volume used in the ultrasound guided stellate ganglion block was found to be the most ideal of $5-10 \mathrm{ml}$ in the quantitative studies ${ }^{8}$. In our case, we injected $10 \mathrm{ml}$ of bupivacaine in the patient's repeated doses. Another beneficial effect of ultrasound guidance is to ensure correct needle placement and protects from dangerous peripheral tissue injections.

We performed intermittent stellate ganglion block in addition to medical treatment (anticoagulant and vasodilator drug) and other supportive therapies. After 
the ganglion block we observed gradual healing in hand's ischemic areas and increased temperature. We could not observe the final result of our treatment, because our patient lost his life due to multiple organ failure.

In conclusion, arterial perfusion of the hand may have impaired secondary to prolonged inactivity, radial artery cannulation, septic embolism, vasospasm and underlying diseases in critical care. Ultrasound guided stellate ganglion block is an alternative treatment option near anticoagulant therapy and vasodilating drugs.

\section{References}

1. Tüzüner F. Anestezi Yoğun Bakım Ağrı 2010;18:11.

2. Tiru B, et al. Radial artery cannulation: A Review Article. J Anesth Clin Res 2012:3:5.

3. Tütüncü AÇ, Kendigelen P, Altıntaş F, Kaya G. Use of Continuous brachial plexus blockade for treatment of accidental intra-arterial injection J Emerg Med Case Rep 2016.

4. Ghouri AF, Mading W, Probaker K. Accidental intraarterial drug injections via intravascüler catheters placed on the dorsum of the hand. Anesth Analg 2002;95(4):487-91.

5. Sen Suriya, Chini EN, Brown MJ. Complications after unintentional intraarterial injections of drugs: Risks, outcomes and manegement strategies Mayo Clin Proc 2005;80:783-95.

6. Kessel G, Barker I. Leg ischemia in an infant following accidental intraarterial administration of atracurium treated with caudal anethesia. Anesthesia 1996;51:1154-56.

7. Özdinç OZ, Evren Şahin K, Göktay A, Onay M, Tarcan E Yanlışlıkla intra-arteriyel atrakuryum enjeksiyonu yapılan pediatrik olgu. Ege Tip Derg 2013;52(4):211-213.

8. Feigl GC, Rosmarin W, Stezl A, et al. Comprasion of different injectate volumes for stellate ganglion block: an anatomic and radiologic study. Reg Anesth Pain Med 2007;32(3):203-208. 